\title{
Triple Functional Domain Protein
}

National Cancer Institute

\section{Source}

National Cancer Institute. Triple Functional Domain Protein. NCI Thesaurus. Code C30129.

Triple functional domain protein (3097 aa, $\sim 347 \mathrm{kDa}$ ) is encoded by the human TRIO gene. This protein plays a role in both guanine nucleotide exchange and serine/threonine kinase activities. 